\title{
Rapid assessment of abrupt urban mega-gully and landslide events with structure-from-motion photogrammetric techniques validates link to water resources infrastructure failures in an urban periphery
}

\author{
Napoleon Gudino-Elizondo ${ }^{1,2}$, Matthew W. Brand ${ }^{2}$, Trent W. Biggs ${ }^{3}$, Alejandro Hinojosa-Corona ${ }^{4}$, \\ Álvaro Gómez-Gutiérrez ${ }^{5}$, Eddy Langendoen ${ }^{6}$, Ronald Bingner ${ }^{6}$, Yongping Yuan ${ }^{7}$, and Brett F. Sanders ${ }^{2}$ \\ ${ }^{1}$ Instituto de Investigaciones Oceanológicas, Universidad Autónoma de Baja California, Ensenada, 22760, Mexico \\ ${ }^{2}$ Department of Civil and Environmental Engineering, University of California, Irvine, California 92697, USA \\ ${ }^{3}$ Department of Geography, San Diego State University, San Diego, California 92182-4493, USA \\ ${ }^{4}$ Departamento de Geología, Centro de Investigación Científica y de Educación Superior de Ensenada, \\ Ensenada, 22860, Mexico \\ ${ }^{5}$ Research Institute for Sustainable Territorial Development, University of Extremadura, Cáceres, Spain \\ ${ }^{6}$ National Sedimentation Laboratory, Agricultural Research Service, USDA, Oxford, Mississippi 38655, USA \\ ${ }^{7}$ Office of Research and Development, US Environmental Protection Agency, \\ Research Triangle Park, North Carolina 27711, USA
}

Correspondence: Napoleon Gudino-Elizondo (ngudino@uabc.edu.mx)

Received: 6 February 2021 - Discussion started: 15 March 2021

Revised: 1 January 2022 - Accepted: 6 January 2022 - Published: 16 February 2022

\begin{abstract}
Mass movement hazards in the form of megagullies and landslides pose significant risks in urbanizing areas, yet they are poorly documented. To obtain primary data on the size, frequency, and triggers of abrupt megagullies and landslides in urban areas, rapid assessment methods based on structure-from-motion (SfM) photogrammetric techniques and watershed models were developed and deployed in the Los Laureles Canyon, a rapidly urbanizing watershed in Tijuana, Mexico. Three abrupt earth surface hazards were observed over a 5-year study period including two mega-gullies and one landslide, and all were linked to a combination of rainfall and water resources infrastructure failures (WRIFs): (1) water main breaks resulted from rainfall-driven gully erosion that undermined supply lines, and the resulting water jets caused abrupt mega-gully formation; this represents one of the first studies to document this process in an urban environment; (2) antecedent saturation of a hillslope from a leaking water supply pipe contributed to an abrupt landslide during a storm event. The return period of the storms that triggered the WRIF-based earth surface hazards was $\sim 1-2$ years, suggesting that such triggering events occur frequently. WRIF-based hazards were
\end{abstract}

also a non-negligible contributor to sediment generation at the watershed scale. While the number of observed events is small, these results suggest that WRIF can, in some cases, be the single most important process generating abrupt and lifethreatening earth surface hazards on the poor urban periphery. Future studies of the triggers and mechanisms of abrupt urban mega-gullies and landslides should consider the role of WRIFs in antecedent saturation and erosion by broken water supply lines.

\section{Introduction}

Mega-gullies and landslides are significant earth surface hazards in urban areas, particularly in marginalized neighborhoods on the periphery of large cities in low- and middleincome countries (Sidle et al., 2011; Anderson et al., 2014; Makanzu Imwangana et al., 2015; Fu et al., 2020). Whereas landslides refer to the movement of sediment down a slope, gullies are landforms comparable to small valleys or ditches that are carved by running water, and mega-gullies imply a width of at least $5 \mathrm{~m}$ (Makanzu Imwangana et al., 2015). 
Mega-gullies and landslides can undermine or damage housing and civil infrastructure and present life-threatening safety risks (Calvello et al., 2016; Peng et al., 2017; McAdoo et al., 2018). Mega-gully and landslide hazards are increasing at a time of rapid urbanization as a result of limited oversight of planning and construction as well as socioeconomic pressures that force populations to settle in high-hazard areas (Hardoy et al., 2013; Retief et al., 2016; Miller et al., 2019). For example, in Latin America, urban expansion on the periphery of large cities often occurs on steep slopes (Sepúlveda and Petley, 2015), and unregulated expansion often results in poorly planned and unmaintained infrastructure that is vulnerable to erosion and destabilization (Griffin and Ford, 1980; Kjekstad and Highland, 2009; Biggs et al., 2010; Bianchini et al., 2017; Costa et al., 2018; de Albuquerque et al., 2020).

Earth surface hazards that occur abruptly (within a few hours) are of particular concern from a safety and damage perspective because there is little time for warnings and other emergency response measures. The literature mainly characterizes the formation of mega-gullies as a result of landscape changes such as deforestation, road construction, and urban development (Archibold et al., 2003; Adediji et al., 2013; Makanzu Imwangana et al., 2015; Zolezzi et al., 2018), although there have been studies documenting abrupt megagully formation in tropical environments (e.g., Moeyersons et al., 2015). In both agricultural and urban areas, gully formation is associated with rain-generated runoff (Valentin et al., 2005). However, mega-gullies may also form abruptly in the presence of a high-velocity water jet from a pressurized pipe, a process similar to hydraulic mining used in mining operations in California during the 19th century (Gilbert, 1917). Furthermore, under rapid urbanization with limited oversight of design and construction, water supply systems are vulnerable to breaks that trigger hydraulic mining and the abrupt formation of mega-gullies on timescales of hours to days. In Tijuana, Mexico, local authorities have observed hazardous mega-gullies from pipe breaks and hydraulic mining (Chief of Civil Protection, Tijuana, Mexico, personal communication, 2016), but the phenomenon has not been documented in the literature. Landslides may also occur abruptly. Landslides refer to a wide range of phenomena associated with the downslope movement of earthen material (e.g., rock or soil) under the influence of gravity. In the Tijuana metropolitan area, rotational soil slides are the most common landslide type and abrupt events have been recognized as a significant threat to public safety (Oliva-González et al., 2014). Landslides occur when the weight of earth material down a slope exceeds its strength (Highland and Bobrowsky, 2008), a process known as overloading that typically occurs with high soil moisture content following rainfall (Kuo et al., 2018; Valenzuela et al., 2018; Zhuo et al., 2019; Monsieurs et al., 2019; Marino et al., 2020) or agricultural intensification (Lacroix et al., 2020). Recent studies have also shown that leaky pipes and septic tanks contribute to overloading (Demoulin and Hans-Balder, 2022). In summary, there is emerging evidence that both water resources infrastructure failures (WRIFs) and rainfall can contribute to abrupt earth surface hazards in urbanizing areas. Furthermore, WRIFs have been documented to play a role in other land surface processes such as the generation of sinkholes (Kim et al., 2018), erosion (Guo et al., 2013), and the destabilization of soil (Van Zyl et al., 2013). However, the occurrence of abrupt mega-gullies and landslides from WRIFs and the interdependence with rainfall are not well documented or understood, which is important to address given the threat of fatalities posed by abrupt hazards and the global growth of urban areas in the Anthropocene (Criqui, 2015; Ercoli et al., 2020).

The monitoring and analysis of abrupt earth surface hazards in urban areas are challenging. Earthwork typically proceeds quickly after an event to clean up or restore sites impacted by displaced sediment, and within days, the site is often so disturbed that it becomes impossible to perform a detailed investigation including the measurement of feature sizes and identification of triggers. Access for monitoring also raises safety concerns due to the steep and unstable slopes. Structure-from-motion ( $\mathrm{SfM}$ ) photogrammetry presents a promising new approach to address these problems. SfM can safely monitor mass movement features with either on-ground or airborne platforms (Nadal-Romero et al., 2015; Eltner et al., 2016; Kaiser et al., 2018; Fugazza et al., 2018; James et al., 2019; Ma et al., 2020) and can be deployed quickly after an event to scan a site - providing data that can be used to estimate the dimensions and volumes of sediment displaced by erosional features. Furthermore, recent advances in the combination of unmanned aerial system (UAS), SfM, and multiview stereo (MVS) algorithms facilitate data acquisition and processing to obtain high-resolution point clouds, digital surface models (DSMs), and orthophotos (Zhang et al., 2019).

Herein we present an observational and modeling study whereby SfM was deployed in a rapid-response mode to document the frequency and magnitude of abrupt earth surface hazards, to document the relative roles of WRIFs and rainfall in hazard formation, and to quantify the amount of sediment generated by the WRIF hazards compared to other rainfallrunoff processes. The study is conducted in the Los Laureles Canyon watershed (LLCW) located in the urban periphery of Tijuana, Mexico, and builds on previous work by the authors to document soil erosion, sediment generation, and flood hazards at the watershed scale (Biggs et al., 2010; Luke et al., 2018; Gudino-Elizondo et al., 2019; Goodrich et al., 2020). To our knowledge, no study has examined the role of WRIFs in abrupt earth surface hazards, a topic of growing importance in the Anthropocene (Vanmaercke et al., 2016, 2021; Poesen, 2018). The objectives of this paper are threefold: (1) to provide primary data on the size, frequency, and triggers of abrupt mega-gullies and landslides that occur in an urban periphery; (2) to demonstrate a SfM-based approach 
suited to the rapid-response needs of abrupt earth surface hazards; and (3) to evaluate the significance of WRIF events with respect to mass movement hazards and sediment budgets at neighborhood and watershed scales.

The remainder of the paper is organized as follows: Sect. 2 ("Materials and methods") presents a site description, SfMbased observational methods, and watershed modeling methods for estimating components of the sediment budget; Sect. 3 (Results) presents SfM and modeling results showing the frequency and magnitude of WRIF-based mass earth surface hazards compared to other mechanisms of sediment generation; Sect. 4 (Discussion) contemplates the relative contribution of rainfall and WRIFs in the observed earth surface hazards and the value of SfM in this context; and major findings are reported in Sect. 5 (Conclusions).

\section{Materials and methods}

\subsection{Site description}

The Los Laureles Canyon watershed (LLCW) is a small $\left(11.6 \mathrm{~km}^{2}\right)$ urbanizing binational watershed on the urban periphery of Tijuana, Mexico (Fig. 1). The LLCW flows from the city of Tijuana, Mexico, into the Tijuana River National Estuarine Research Reserve, USA (Fig. 1). Excess sedimentation into the estuary, which is due to high sediment loads from Tijuana, has buried and impaired the estuarine ecosystem (Weis et al., 2001).

The climate in the LLCW is Mediterranean, with a wet winter, a dry summer, and average annual precipitation of $240 \mathrm{~mm}$. The regional geology includes marine and fluvial deposits of conglomerate, sandy conglomerate, and siltstone of the San Diego formation (Gastil et al., 1975; Minch et al., 1984). Soils are generally sandy with a wide range of cobble fraction and are dominated by steep slopes $\left(15^{\circ}\right.$, average). Urbanization in the LLCW started in 1962, with most urbanization occurring between 1980 and 2002 (Biggs et al., 2017), mostly in the form of unauthorized housing developments (invasiones). Unauthorized construction of poorly planned housing, water distribution networks, and roadways on steep slopes concentrated stormwater runoff and increased soil and gully erosion, slope instabilities, and failures in WRI. The LLCW is on the western periphery of Tijuana; the socioeconomic status of residents in the LLCW is low in the southern part of the watershed and in the areas with infrastructure failure as evidenced by a high marginality index and a low fraction of homes with piped water or drainage as compared with other areas of Tijuana (Biggs et al., 2014).

\subsection{Study design}

Hydrologic conditions, slope instabilities, and sediment generation rates were monitored in the LLCW for a 5-year period beginning in January 2013 and ending in April 2018. A tipping-bucket rain gauge station ("LLCW Rain gauge" in

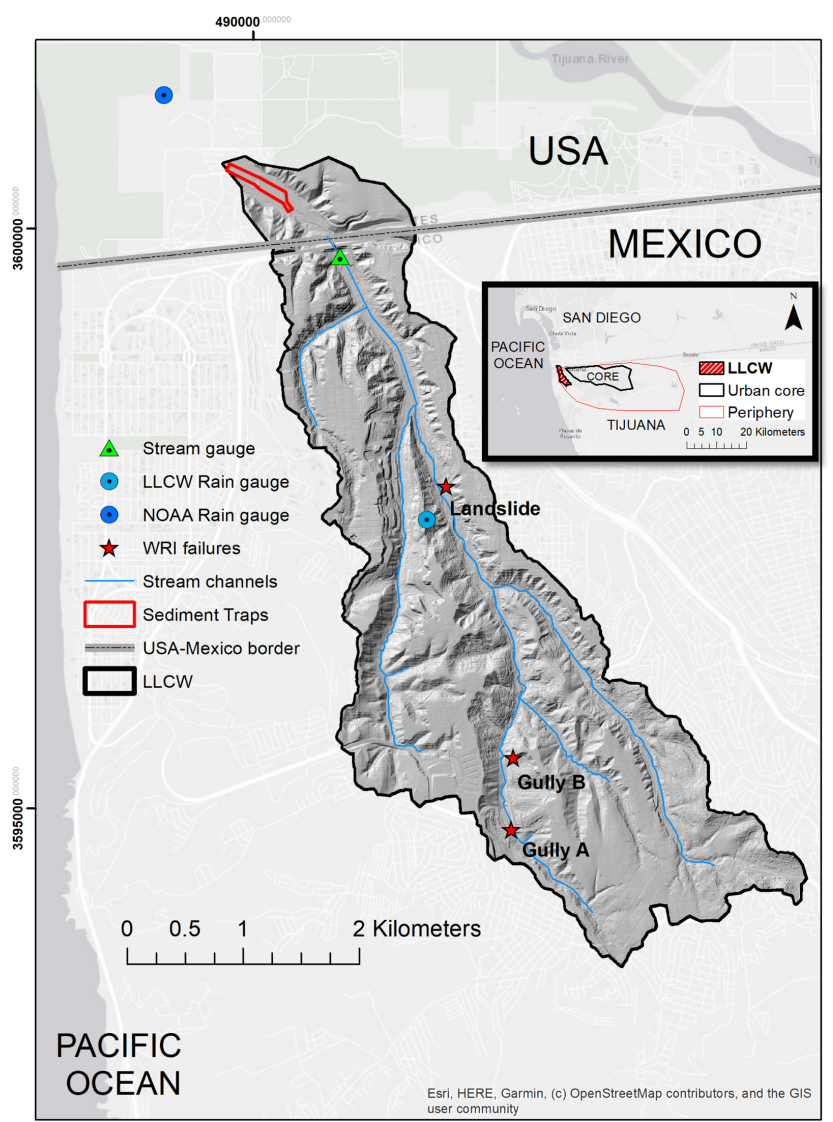

Figure 1. The Los Laureles Canyon watershed (LLCW), locations of water resources infrastructure failures (WRIFs), and field equipment. Inset shows the regional location of the LLCW within the urban periphery. Base map (C) OpenStreetMap contributors 2020. Distributed under the Open Data Commons Open Database License (ODbL) v1.0.

Fig. 1) was installed in the watershed, and a pressure transducer (PT) (Solinst, water level logger) was installed in a concrete channel at the watershed outlet and logged the water level at $5 \mathrm{~min}$ intervals (Fig. 1). Upon detection of flow at the watershed outlet, field personnel traveled to the site; performed a visual inspection of site conditions; and, upon observation of mega-gullies and landslides, collected two types of data about the WRIF erosional features: (1) photogrammetric surveys (RGB images) were performed using either a ground-based or an aerial platform, and (2) ground control points (GCPs) were acquired by differential GPS (Magellan ProMark 3) with sub-centimeter to $5 \mathrm{~cm}$ accuracy (Magellan Systems Corporation, San Dimas, California, USA). These primary data were used to create DSMs and, in turn, estimates of sediment volumes and their impacts on sediment budget, as well as to document safety hazards to the people living in the watershed downstream ecosystems.

A long-term record of rainfall is available from the NOAA Tijuana River estuary gauging station, located near the outlet of the LLCW, which provides daily rainfall for the pe- 
Table 1. Structure-from-motion survey description and data acquisition. GCPs and ECPs denote ground control points and error control points, respectively. UAS denotes unmanned aerial system.

\begin{tabular}{llll}
\hline Erosional feature & Landslide & Mega-gully A & Mega-gully B \\
\hline Acquisition platform & UAS & UAS & Pole \\
Date of survey & 22 May 2015 & 23 Sep 2015 & 17 Feb 2017 \\
Number of pictures & 62 & 115 & 899 \\
Altitude (m) & $75 \mathrm{~m}$ & $30 \mathrm{~m}$ & $4 \mathrm{~m}$ \\
Area covered $\left(\mathrm{m}^{2}\right)$ & 38400 & 1800 & 2800 \\
Ground sample distance $\left(\mathrm{cm} \mathrm{px}^{-1}\right)$ & 10 & 4 & 3 \\
Point density (points per $\left.\mathrm{m}^{2}\right)$ & 11 & 48 & 261 \\
Numbers of GCPs & 8 & 8 & 12 \\
Numbers of ECPs & 6 & 6 & 10 \\
Pre-event topography & Lidar DSM & $\mathrm{SfM}$ & $\mathrm{SfM}$ \\
\hline
\end{tabular}

riod 1980 to 2018 , and estimates of daily rainfall back to $\sim 1950$ were reconstructed by regression with a nearby gauge at the Lindbergh airfield in San Diego (Brand et al., 2020). A tipping-bucket rain gauge (LLCW Rain gauge in Fig. 1) was previously used to force a watershed erosion model which was validated with stream gauge data and observed sediment loads at the outlet (Gudino-Elizondo et al., 2019), and this model was applied here to estimate rates of sediment generation by sheetwash, rill, gully, and channel erosion estimated for comparison with sediment volumes documented by SfM as described next.

\subsection{Image acquisition and processing}

Photogrammetric surveys were performed using a modified nonmetric camera (GoPro Hero3+) with a nondistortion lens, $4.14 \mathrm{~mm}$ focal length, $f / 3.0$ aperture, and 12-megapixel image size (Peau Productions, California, USA, http://www.peauproductions.com/, last access: February 2022) mounted on either an unmanned aerial system (UAS) (DJI, Phantom2) or a telescoping painter's pole (approximately $2-3 \mathrm{~m}$ long). The UAS is advantageous for relatively large and wide erosional features compared with the painter's pole, which can better access relatively small, narrow, and deep erosional features (Gudino-Elizondo et al., 2018a; Taniguchi et al., 2018). Images were acquired once per second using the time-lapse capture mode from different angles to ensure a high overlap between photographs and to reduce the shade in each image (Castillo et al., 2015) and doming deformations (James and Robson, 2014).

The sediment volume mobilized was estimated using a four-step procedure: (1) imagery was combined with a subset of the GCPs to calibrate the camera and produce structurefrom-motion (SfM) point clouds following general workflows (Agisoft LCC, Russia, Version 1.4.4), (2) SfM point clouds were converted to a digital surface model (DSM) (Agisoft LCC, Russia, Version 1.4.4); (3) erosional volumes were computed (ArcGIS 10.6.1, Esri, Redlands, California, USA) by subtracting the DSM from a reference DSM repre- sentative of the pre-event land surface (Wheaton et al., 2010); (4) the difference in DSMs (DiD) was integrated to calculate the total sediment volume (James et al., 2012). Volumes were converted to mass using a bulk density of $1600 \mathrm{~kg} \mathrm{~m}^{-3}$ corresponding to very fine sand (USDA, 2018).

Pre-event topography was based either on a 2014 aerial lidar survey ( $1 \mathrm{~m}$ resolution digital surface model - DSM with a $0.11 \mathrm{~m}$ vertical RMSE; NOAA, 2021) or on UASbased DSMs generated with imagery collected before the failure event (Table 1). The horizontal and vertical RMSE of the point clouds, or geo-registration error, was estimated using the subset of the GCPs not used to produce the SfM point cloud, called error control points (ECPs). Previous work indicates that four to five GCPs with a few additional ECPs are adequate for SfM processing (James et al., 2017). The RMSE for the DiD was computed as the square root of the sum of the squared errors for each DSM (Alfonso-Torreño et al., 2019).

The dimensions of invariant features (concrete pads, water pipes, etc.) were directly measured in the field and compared to length estimates from the SfM point cloud as described in Gudino-Elizondo et al. (2018a). Additionally, pre- and postevent ground elevations were compared along transects outside the disturbed region where no topographic change was observed to assess co-registration errors in the DiDs' calculation.

\subsection{Watershed modeling}

The Annualized AGricultural Non-Point Source (AnnAGNPS) model (Bingner et al., 2015) was applied to the LLCW to simulate discharge and sediment load during storm events and to develop an inventory of sediment generation rates by mechanism at the watershed scale. The AnnAGNPS model was previously calibrated and validated for runoff and observations of sediment generation in the LLCW (GudinoElizondo et al., 2018a, b, 2019), and the applications here rely on this calibration. The simulation period was from water year 2012 to 2017 to match the observation period of the 
mega-gullies and landslide. Sediment excavation rates from sediment traps at the LLCW outlet (Fig. 1) were used for model calibration. The sediment traps were excavated annually from 2007-2012 $(N=7)$. Uncertainties in the modeled sediment yield were previously reported by GudinoElizondo et al. (2019) as approximately $10 \%$, with a normalized RMSE of $48 \%$.

Measurements and modeling supported an inventory of sediment generation and load from four mechanisms: (1) sheet and rill erosion, (2) gully erosion, (3) channel erosion, and (4) erosion from WRIF. Sediment generation was considered the total mass of sediment mobilized, while the sediment load was the quantity of sediment observed at the watershed outlet. Sediment load from WRIF was calculated by multiplying the erosion volume per event times the sediment delivery ratio (SDR). For mega-gullies, the SDR was set to 1 based on field observations and modeling work described in Gudino-Elizondo et al. (2019). Conversely, the SDR was set to zero for the landslide based on field observations that displaced sediment was intercepted by the road network and mechanically removed or repositioned on the hillslope (Vigiak et al., 2012). Subsequent rainfall events may cause the repositioned sediment to be later mobilized and moved towards the stream network, so our estimates of load correspond only to the period of observation.

\subsection{Hazard assessment from water resources infrastructure failure}

Reports of the damage caused by mega-gullies and the landslide were compiled from residents and local agencies. Primary data from the three events are described, including impacts to transportation, housing, urban infrastructure, and downstream ecosystems and communities in the study watershed. The year of urbanization of the neighborhoods where the WRIFs occurred was determined from an existing dataset (Biggs et al., 2010). The specific soil loss (SSL) of the WRIF mega-gullies was calculated as the total erosion $\left(\mathrm{m}^{3}\right)$ normalized by the watershed area $\left(\mathrm{m}^{2}\right)$ and was then compared to the observed SSL in the study watershed and to other studies reported in the literature. A detailed description of safety hazards and the contribution to the total sediment budget of each WRIF event is given in Sect. 3.

\section{Results}

\subsection{WRIF-based mass movement events}

A total of 14 storm events were observed during the 5year study period, based on a flow threshold of $1 \mathrm{~m}^{3} \mathrm{~s}^{-1}$ (or $\sim 15 \mathrm{~cm}$ of water in the channel) at the gauging station, which corresponds to a depth of rainfall ranging from 6.5 to $13 \mathrm{~mm}$. The total depth of the 14 storms was $322 \mathrm{~mm}$, or $35 \%$ of the total rainfall $\left(907 \mathrm{~mm}, 181 \mathrm{~mm} \mathrm{yr}^{-1}\right)$ for the 5 -year period. Mass movement from WRIFs was observed during three of these events, each characterized by a 1-2year return period based on precipitation depth frequency information reported by NOAA Atlas 14 for the nearby Imperial Beach, California (NOAA, 2021). WRIFs leading to mass movement were not observed between storm events or during smaller storm events $(<23 \mathrm{~mm})$. Figure 2a shows the reconstructed rainfall time series for the period 19502017, which demonstrates variability over roughly 7 decades, and Fig. $2 b$ shows the timing of WRIF-based mass movement events alongside measured daily rainfall for 20132017. Both mega-gully events are associated with rainfall that exceeds the threshold for rainfall-driven gully formation reported by Gudino-Elizondo et al. (2018a) but is not exceptional in magnitude considering the long-term record. The year of urbanization of the neighborhoods was 1980 (landslide), 2010 (mega-gully A), and 2002 (mega-gully B). Hence, the landslide is associated with a later stage of urbanization (34 years) compared to mega-gully A (4 years) and mega-gully B (15 years).

\subsubsection{Landslide}

A large rotational landslide occurred during a storm event on 15 May 2015 (Fig. 3a and b). More than 20 houses and public transportation were damaged permanently, affecting hundreds of people. Based on the daily rainfall total $(23 \mathrm{~mm})$ and the long-term rainfall record at the NOAA Tijuana River estuary gauge, the return period of the storm is 1 year. The landslide was attributed to a WRIF based on resident reports of seepage from the slope for several days immediately before the failure incident and prior to rainfall and of broken water mains observed after the landslide (Fig. 3c, and d, red circle). Observation of incipient cracks in the soil prior to failure also triggered the evacuation of the residents. The main scarp was approximately $20 \mathrm{~m}$ high and approximately $75 \mathrm{~m}$ long, with a maximum width of $40 \mathrm{~m}$ measured from the main scarp to the toe of the hill. SfM photogrammetry leads to an estimate for the sediment volume and mass: $19900 \pm 170 \mathrm{~m}^{3}$ and $31900 \pm 280 \mathrm{t}$. The reported uncertainties ( \pm value) are obtained by propagating vertical RMSEs of individual DSMs in the DiD calculation.

The RMSE (ECPs, $n=6$ ) of the DSM obtained from SfM was $3 \mathrm{~cm}$ in the horizontal and $7 \mathrm{~cm}$ in the vertical coordinates. Elevation differences outside of the disturbed area were $<7 \mathrm{~cm}$. Therefore, the co-registration error is assumed to be negligible. The mean difference between measured and modeled lengths of objects at the site (e.g., sewer manhole covers) was less than $3 \mathrm{~cm}$. These different methods all suggest the error was less than $7 \mathrm{~cm}$ and within the range expected for the observation distance. The DiD map (Fig. 3c) shows the geometry of the landslide as a deep rotational slope failure, which is consistent with the model proposed by Highland and Bobrowsky (2008). 
(a)

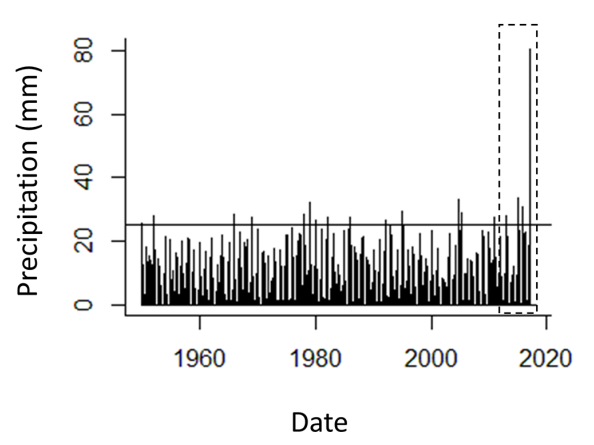

(b)

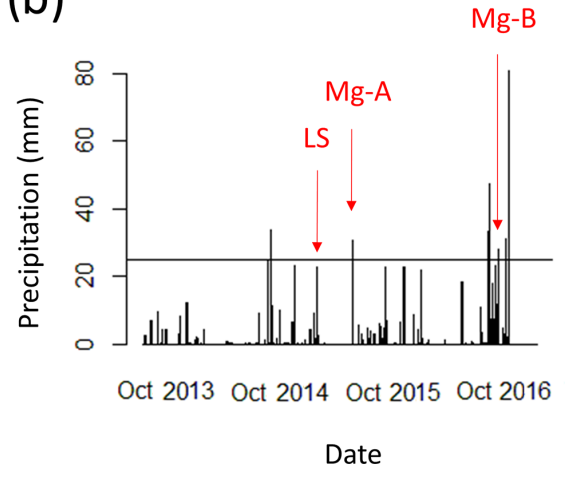

Figure 2. (a) Reconstructed daily rainfall time series measured at the watershed outlet for 1950-2017, with the horizontal line representing the rainfall threshold for rainfall-runoff gullies formation (Gudino-Elizondo et al., 2018a); (b) measured rainfall for water years $2013-2017$ and timing of the observed mega-gullies (Mg) and landslide (LS).
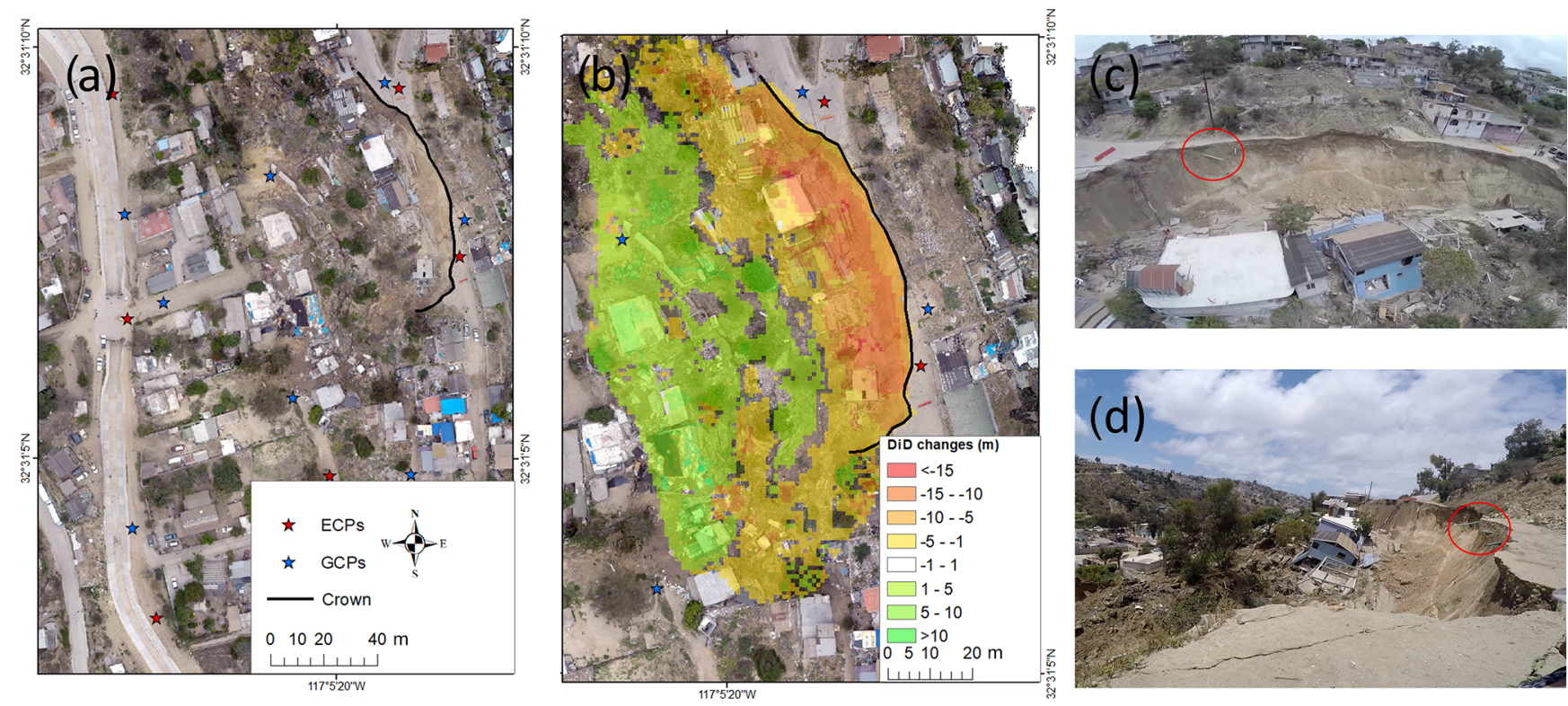

Figure 3. Landslide event on 15 May 2015 triggered by water main leak and rainfall: (a) orthophoto acquired after the WRIF showing the upper limit of the main scarp (crown) with the black line, (b) the DiD changes from the multi-temporal analysis, and (c) oblique aerial and (d) ground-based photographs of the landslide showing broken water mains inside the red circle aligned with the main scarp.

\subsubsection{Mega-gully A}

Mega-gully A formed along an unpaved road during and immediately following a storm event on 15 September 2015. Based on the daily rainfall total $(31 \mathrm{~mm})$ and the long-term rainfall record at the NOAA rain gauge, the return period of the storm was 1-2 years. This mega-gully was attributed to a WRIF based on resident reports that discharge from a broken pipe was observed upstream immediately after the failure event (Tijuana Metropolitan Planning Institute, personal communication, 2015). In this case, erosion caused by the storm event undermined the water main, which subsequently broke and enlarged the gully as a result of high-velocity water jets from the pressurized water main. The mega-gully was
$98 \mathrm{~m}$ long, with a maximum width of $8 \mathrm{~m}$ and maximum depth of $4 \mathrm{~m}$ (Fig. 4). The generated sediment mass was estimated as $1360 \pm 35 \mathrm{t}$.

The RMSE (ECPs, $n=6$ ) of the DSM obtained from SfM was $3 \mathrm{~cm}$ horizontally and $5 \mathrm{~cm}$ vertically. Elevation differences outside of the disturbed area were $0-5 \mathrm{~cm}$. Field measurements of the mega-gully width and depth differed from the SfM-derived width and depth by less than $2 \mathrm{~cm}$ on average. This WRIF caused interruption to the water supply for 1 month, affecting more than 300 residents (Tijuana Metropolitan Planning Institute, personal communication, 2017). The corresponding erosional feature impacted public transportation and life quality in the neighborhood 

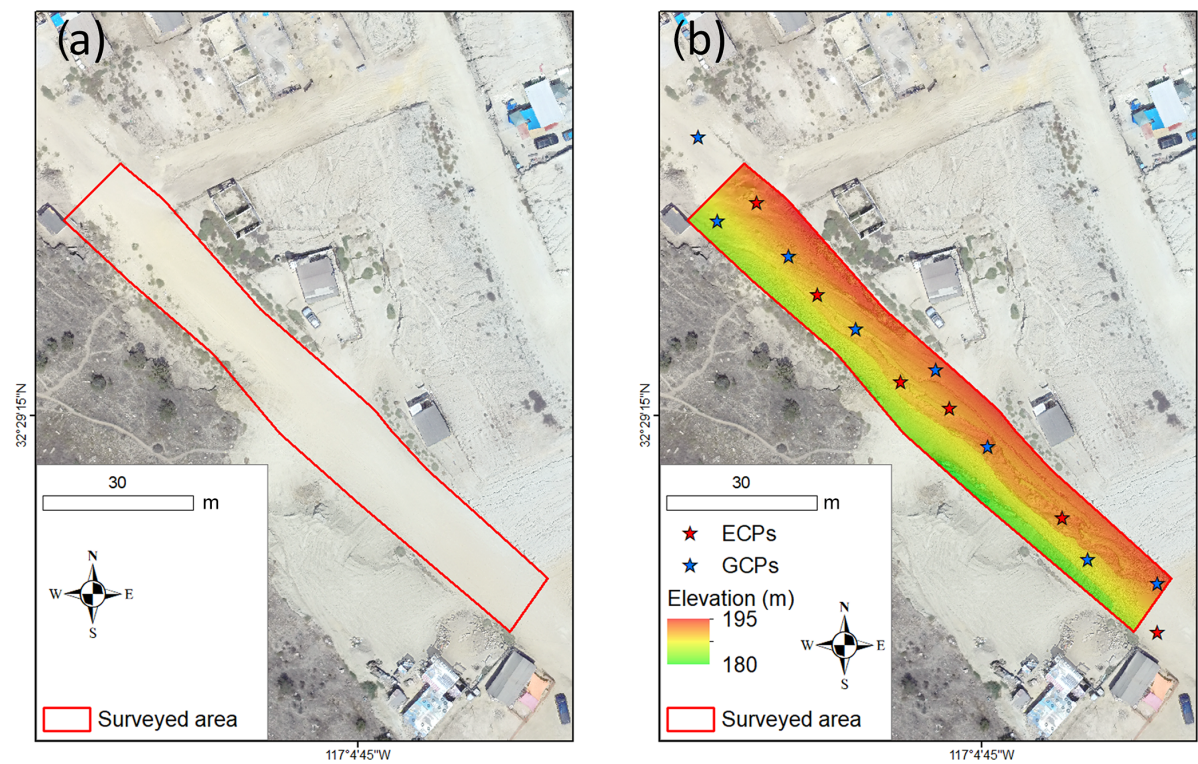

Figure 4. Mega-gully A formed on 15 September 2015 by WRIF: (a) orthophoto acquired before the WRIF showing the extent of the surveyed area centered on the red rectangle and (b) the resulting DSM showing the spatial distribution of ground control points and error control points (GCPs and ECPs, respectively).

for 6-9 months (available Google Earth imagery 11 December 2015-8 August 2016) before the road was repaired.

\subsubsection{Mega-gully B}

A second mega-gully (B) formed along an unpaved road (Fig. 5a) following a storm event on 16 December 2016. Based on the daily rainfall total $(33 \mathrm{~mm})$ and the long-term rainfall record at the NOAA rain gauge, the return period of the storm was 1-2 years. The mega-gully was largest at the upslope position and decreased in cross-sectional area with distance from the broken pipeline. The mega-gully was $202 \mathrm{~m}$ long, with a maximum width of $10 \mathrm{~m}$ and maximum depth of $7 \mathrm{~m}$. Imagery was collected for the SfM processing using a telescoping painter's pole, and sediment generation was estimated to be $4340 \pm 155 \mathrm{t}$.

The RMSE (ECPs, $n=10$ ) of the DSM (Fig. 5b) obtained from $\mathrm{SfM}$ was $3.5 \mathrm{~cm}$ in the horizontal and $5 \mathrm{~cm}$ in the vertical. Elevation differences outside of the disturbed area were $0-5 \mathrm{~cm}$, which is consistent with the accuracy of the method. For example, differences between measured and modeled lengths of non-deforming objects at the site (e.g., water supply pipes shown as white arrows in Fig. 5c and d) were less than $1 \mathrm{~cm}$.

For this second mega-gully event, mass movement was again triggered by erosion that undermined the water main, which subsequently broke and enlarged the gully by discharging piped water directly onto the hillslope. Broken water main pipes were observed during the rapid-response survey (Fig. 5c). The mega-gully also impacted public transportation and life quality in the neighborhood for 6 months (based on Google Earth imagery) and interrupted water supply for 1 month, affecting more than 200 people (Tijuana Metropolitan Planning Institute, personal communication, 2017).

\subsection{Comparison of sediment generation sources}

Application of the calibrated AnnAGNPS watershed model to storm events for 2012-2017 yielded daily estimates of rainfall-based sediment generation by sheet and rill erosion, gully erosion, and channel erosion. Table 2 presents sediment generation (by mass) on a storm-event basis, showing the amount of sediment generation associated with WRIFs measured using SfM and the simulated total watershed sheet and rill erosion, gully erosion, and channel erosion at the event scale. Additionally, Fig. 6 shows the relative contribution of WRIF and rainfall-based sediment generation mechanisms.

Mass movement associated with WRIFs was significant on an event basis. Mega-gully B generated $4340 \mathrm{t}$ (Table 2), which is approximately 80 times the area-normalized annual erosion rate for gullies $\left(\mathrm{tha}^{-1}\right)$ and 10 times the total sediment generated by other rainfall-generated gullies (GudinoElizondo et al., 2018a, b). The WRIF-triggered landslide mobilized more sediment than all of the rainfall-based processes combined, while the mega-gullies triggered by pipe failures and hydraulic mining were responsible for $16 \%$ and $20 \%$, respectively, of the total sediment generation across the watershed (Fig. 6).

The proportion of sediment generated by each erosional process differed markedly between the landslide event and the two mega-gully events (Fig. 6); rainfall-generated gul- 

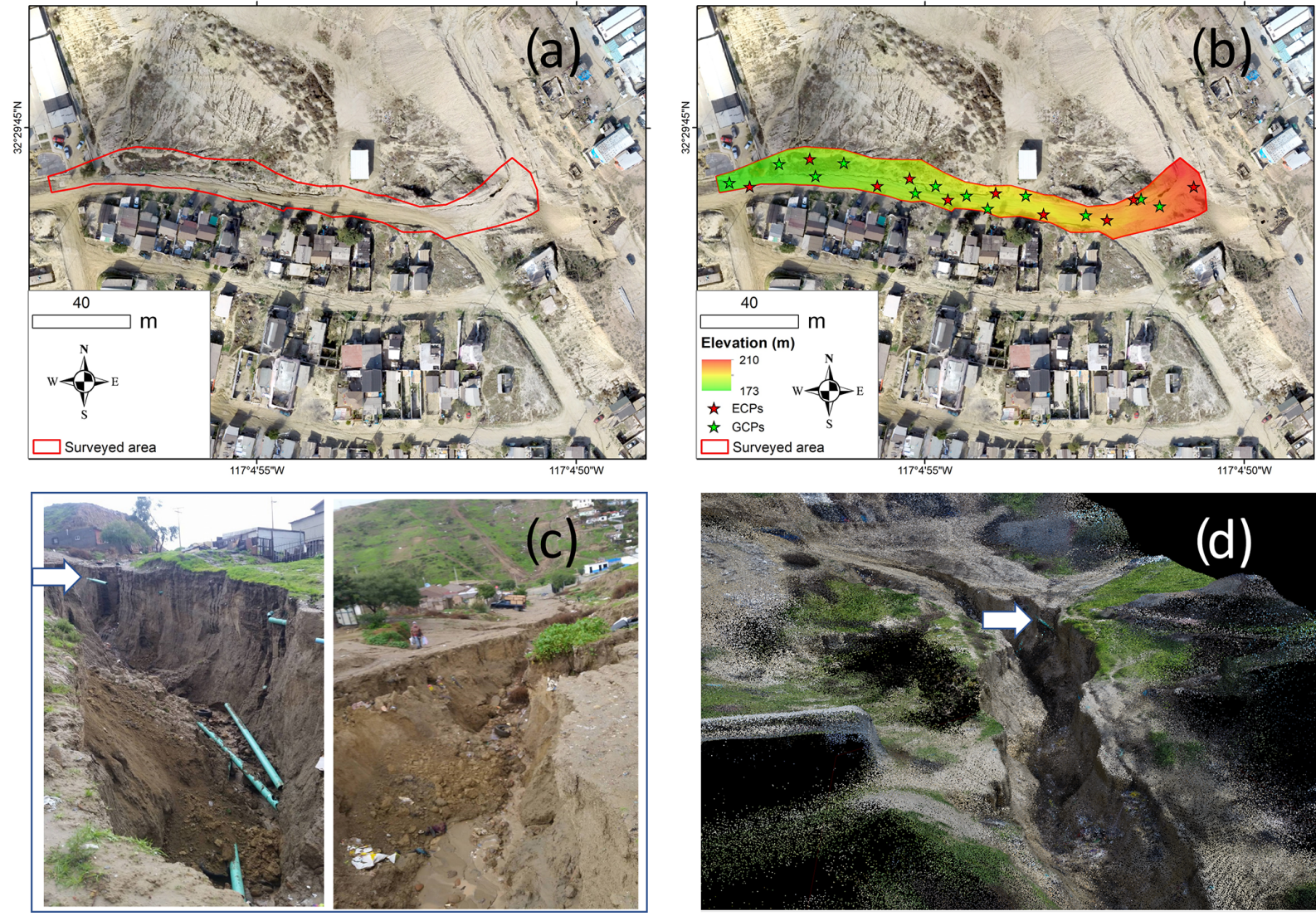

Figure 5. Mega-gully B formed on 16 December 2016 triggered by WRIF: (a) orthophoto acquired before the WRIF showing the extent of the surveyed area centered on the red polygon, (b) the resulting DSM after the WRIF, (c) images depicting the mega-gully with view angles looking upslope and downslope of the WRIF, and (d) a screenshot of the resulting point cloud.

Table 2. Sediment generation by process during storm events with WRIFs in the Los Laureles Canyon watershed.

\begin{tabular}{|c|c|c|c|c|c|}
\hline \multirow{3}{*}{$\begin{array}{l}\text { Erosional hazard } \\
\text { event }\end{array}$} & \multicolumn{5}{|c|}{ Sediment generation mechanism $(\mathrm{t})$} \\
\hline & \multicolumn{2}{|c|}{ Measured } & \multicolumn{2}{|c|}{ Modeled } & \multirow[t]{2}{*}{ Total } \\
\hline & $\begin{array}{r}\text { Water } \\
\text { resources } \\
\text { infrastructure } \\
\text { failures }\end{array}$ & $\begin{array}{l}\text { Channel } \\
\text { erosion }\end{array}$ & $\begin{array}{r}\text { Sheet and } \\
\text { rill }\end{array}$ & $\begin{array}{r}\text { Rainfall- } \\
\text { runoff } \\
\text { gullies }\end{array}$ & \\
\hline Landslide & $31900 \pm 280$ & 7610 & 5310 & 10500 & 55300 \\
\hline Mega-gully A & $1360 \pm 35$ & 2290 & 4710 & 49 & 8410 \\
\hline Mega-gully B & $4340 \pm 155$ & 5910 & 12100 & 160 & 22500 \\
\hline
\end{tabular}

lies contributed more sediment during the landslide event because peak discharge, the main control on gully formation, was higher during the landslide storm event $\left(19.5 \mathrm{~m}^{3} \mathrm{~s}^{-1}\right.$ at the outlet) than during the two mega-gully events ( $5 \mathrm{~m}^{3} \mathrm{~s}^{-1}$ ) (Gudino-Elizondo et al., 2019).

The total sediment generation and load were computed for the 5-year study period by integrating over all storm events (Table 3). On a 5-year basis, WRIFs contributed $5 \%$ of the total sediment generation and approximately $2 \%$ of the to- tal sediment load at the watershed scale. While the sample size here is small, the frequency of WRIF-based erosional events can be estimated in several ways: three hazard events occurred over a period that had 14 rainfall events $(21 \%$ of rainfall events), 2 out of 5 years had at least one hazard event (40\% chance per year), or three events occurred in 5 years (60\% chance per year). The small sample size implies a high degree of uncertainty in all of these estimates; nevertheless, these rates of occurrence are far higher than typical design 
Landslide

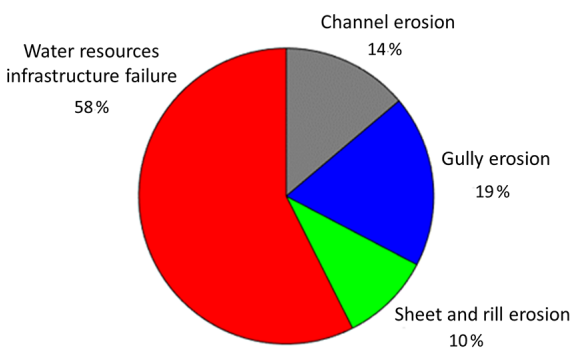

Mega-gully A

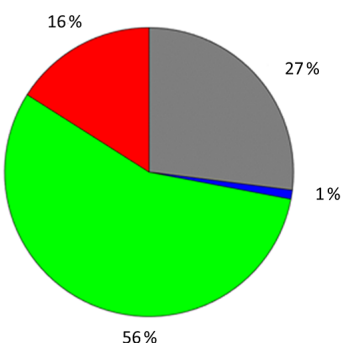

Mega-gully B

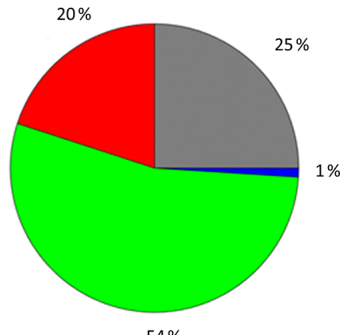

Figure 6. Relative contribution of sheet and rill erosion, gully erosion, channel erosion, and water resources infrastructure failure (WRIF) towards sediment generation for three storm events with WRIF.

standards for water resources infrastructure in urban areas. For example, large flood control channels are typically designed with a $0.2 \%-2 \%$ annual exceedance probability, and smaller drainage systems in urban areas are often designed for $5 \%-10 \%$ annual exceedance probability. Hence, WRIFbased hazards observed during this study are many times more frequent ( $21 \%-60 \%)$ than typical design standards for flood control systems in urban areas $(0.2 \%-10 \%)$ and thus deserving of greater attention for public safety, infrastructure resilience, and environmental protection.

\subsection{Comparison to other erosional features}

The mega-gullies observed here are large compared to rainfall-generated gullies surveyed in the study area (GudinoElizondo et al., 2018a), which had a mean gully width of $1.5 \mathrm{~m}$ and a mean depth of $0.5 \mathrm{~m}$. In terms of size, megagully $\mathrm{A}$ was up to $8 \mathrm{~m}$ wide and $4 \mathrm{~m}$ deep and mega-gully $\mathrm{B}$ was up to $10 \mathrm{~m}$ wide and $7 \mathrm{~m}$ deep. Mega-gullies A and B were also long with lengths of 100 and $200 \mathrm{~m}$, respectively. They were also more developed than rainfall-generated gullies, with greater connectivity to the stream channel, which enhances sediment delivery to the stream network. Figure 7 presents an aerial image which provides a visual comparison of mega-gully $\mathrm{B}$ to a rainfall-driven gully network on a neighboring unpaved road.

Figure 8 shows that the specific soil loss (SSL, the average depth of soil loss in the watershed) from mega-gully B was exceptionally high compared to rainfall-runoff gullies in the LLCW (Gudino-Elizondo et al., 2018a) and compared to sites reported by Castillo and Gómez (2016), which included sites spanning different land uses and precipitation regimes. The SSL from mega-gully A was comparable to other gullies observed in the study watershed, which has higher rates of SSL than the set of sites reported by Castillo and Gómez (2016).

The landslide caused by the WRIF was the single largest erosional feature observed in the watershed during the study period. Landslides occur throughout Tijuana, with more than 40 landslides from 1992-2012, including a landslide that

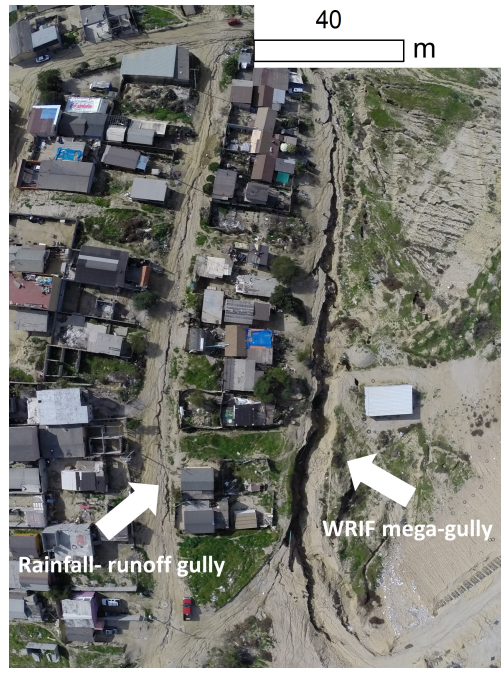

Figure 7. High-resolution photograph showing the contrast between gullies generated by rainfall-runoff only (road on left) and megagully B (road on right).

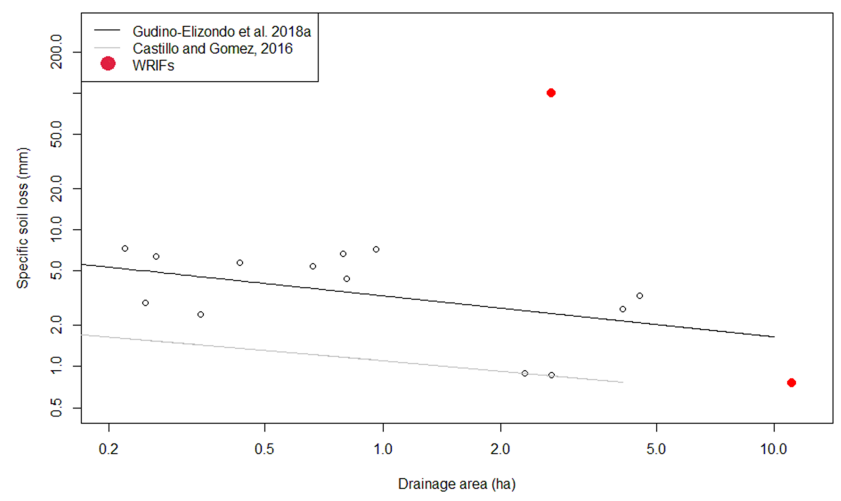

Figure 8. Specific soil loss of mega-gullies caused by WRIF (red dots) compared to previously reported gullies in Tijuana, Mexico (circle points and black line; Gudino-Elizondo et al., 2018a), and trends for ephemeral gullies reported from other sites (gray line; Castillo and Gómez, 2016). 
Table 3. The 5-year total sediment generation and load rates (by process), fraction of total generation, and fraction of total load for the Los Laureles watershed.

\begin{tabular}{lrrrr}
\hline $\begin{array}{l}\text { Generation } \\
\text { mechanism }\end{array}$ & $\begin{array}{r}\text { 5-year } \\
\text { total } \\
\text { sediment } \\
\text { generation } \\
(\mathrm{t})\end{array}$ & $\begin{array}{r}\text { 5-year } \\
\text { total } \\
\text { sediment } \\
\text { load } \\
(\mathrm{t})\end{array}$ & $\begin{array}{r}\text { Fraction } \\
\text { of total } \\
\text { generation } \\
(\%)\end{array}$ & $\begin{array}{r}\text { Fraction } \\
\text { of total } \\
\text { load (\%) }\end{array}$ \\
\hline WRIF & 37566 & 5696 & 5 & 2 \\
Sheet and rill & 258592 & 197538 & 34 & 48 \\
Rainfall-runoff gullies & 228207 & 75253 & 30 & 18 \\
Channel erosion & 234150 & 131212 & 31 & 32 \\
\hline Total & 758515 & 409699 & 100 & 100 \\
\hline
\end{tabular}

damaged 19 buildings (Oliva-González et al., 2014), which is comparable to the LLCW slide (20 buildings damaged). However, data describing the sediment displaced by these 40 landslides and potential connections to WRIFs were not available. More research is needed to establish the links between WRIFs and landslides.

\section{Discussion}

\subsection{Rapid methods for monitoring erosional features}

Landslides and mega-gullies have complex topographies and are poorly suited to the application of traditional surveying techniques such as total stations, but they are well suited to photogrammetric characterization using SfM. In our study, photogrammetric data were effectively captured for megagullies roughly 5-10 m wide, 5-10 m deep, and $>100 \mathrm{~m}$ long using a camera mounted on a telescoping painter's pole, and landslides were safely characterized using a UAS-based platform. James and Robson (2012) introduced the relative precision ratio for UAS-SfM applications (i.e., the ratio of measurement precision to observation distance) and found that a precision ratio of $1: 950$ indicates acceptable accuracy over a range of scales. For a flight height of $75 \mathrm{~m}$, the James and Robson (2012) standard gives a desired DSM error of $7.8 \mathrm{~cm}$, which compares well with the horizontal $(3 \mathrm{~cm})$ and vertical $(7 \mathrm{~cm})$ errors estimated here. The errors in the DSMs were very small $(\leq 5 \mathrm{~cm})$ compared to the size of the features $(5-10 \mathrm{~m})$. The presence of urban infrastructure in photographs (e.g., concrete pads, sewer structures) also presented opportunities for ground control points and accuracy checks. Elevation differences outside of the disturbed areas were $<7 \mathrm{~cm}$, indicating minimum co-registration errors. Errors in sediment volume estimates were also small (1\% to $3 \%$ ). The DiD also helped to characterize the landslide as a deep rotational slope failure, consistent with other landslides reported in Tijuana, which are linked with unplanned urbanization on hilltops and enhanced pore pressure induced by uncontrolled water leakage (Oliva-Gonzalez et al., 2014). We also note from the DSM analyses that the terrain slope was associated with the depth of the incision of WRIF mega-gullies. Mega-gully B was 2-3 times deeper than mega-gully $\mathrm{A}$, which formed on a relatively flat area. Accuracies achieved from these observations, from both individual point clouds and DiD calculations, are in line with the needs for erosion hazard surveys and sediment budget applications (Dietrich, 2016; Alfonso-Torreño et al., 2019; Ma et al., 2020). The SfM photogrammetric approach is in many ways ideal for surveying WRIFs because (1) the camera is lightweight and easily mounted on either a groundbased or an aerial platform; (2) SfM requires fewer field personnel, reducing significantly human-based errors, and is more time efficient than traditional topographic surveying methods (Carrera-Hernández et al., 2020); and (3) hardware costs are relatively low. Laser scanning or lidar systems could be advantageous compared to photogrammetry in terms of point density and data accuracy, but they are typically quite heavy compared to cameras, require more sophisticated spatial referencing systems (e.g., inertial navigation units), often present occlusion artifacts, and are expensive (Izumida et al., 2017; Mazzoleni et al., 2020). Our study demonstrates that both ground-based and UAS-based photogrammetry allow for rapid documentation of hazardous erosional features with minimal equipment and low labor requirements. Recent advances in UAS-mounted real-time kinematic or post-processing kinematic (RTK, PPK) georeferencing systems allow rapid mapping over relatively large areas without GCPs (Zhang et al., 2019), enhancing the potential for rapidresponse-survey programs, especially in dangerous and inaccessible terrain.

\subsection{WRIFs and the sediment budget}

Stochasticity in WRIFs and WRIF-based sediment hazards is high. Failures may or may not happen in any given storm (here we observed three failures in 14 storm events), and when failures occurred, the volume of sediment generated across three events varied by over an order of magnitude. This makes it difficult to generalize and estimate sediment 
generation by infrastructure failure for other events lacking field observations. However, the data do allow a firstorder estimate of annual-average sediment generation from WRIFs, which is useful for sizing sediment basins that protect downstream ecosystems from excess sedimentation and for estimating average-annual excavation costs. We found in previous research that rainfall-runoff gully erosion rates are higher on steep sandy soils (Las Flores soil type) (GudinoElizondo et al., 2019), and a rainfall threshold to generate rainfall-runoff gullies on those unpaved roads $(>25 \mathrm{~mm}$ ) was also observed (Gudino-Elizondo et al., 2018a). Therefore, WRIF mega-gullies in Tijuana are more likely to occur on sandy soils on steep terrain during storm events equal to or greater than the threshold precipitation typically required to produce rainfall-runoff gullies on unpaved roads (Fig. 2). Such estimates would not likely be applicable outside of the LLCW, but the photogrammetric methods deployed here to monitor sediment generation are easily transferrable to other systems, and data on sediment generation from multiple sites would provide a basis for improved understanding and possibly transferrable models.

\subsection{Feedbacks between urbanization processes, erosion, and slope instabilities from WRIFs - opportunities for hazard mitigation}

Erosion and hazards produced by WRIFs were either exacerbated or triggered by erosion during storm events. The observed landslide was triggered by a storm event, but the event was preceded by the water main leak that created the preconditions for a landslide. The observed mega-gullies formed after local runoff initially undermined water mains, which then broke and discharged water onto the hillside, triggering more severe gully erosion. This suggests that WRIFs, storm events, and slope instabilities are interdependent. Moreover, this opens the possibility of reducing mass movement hazards through improved design, management, and oversight of water resources infrastructure. Whereas rapid urbanization is broadly linked to minimal levels of governance and institutional oversight of urban infrastructure, especially in the least-developed countries (Borelli et al., 2018), water resources infrastructure benefits from relatively high levels of planning, design, engineering, and oversight (Whittington et al., 2009; Cook, 2011). For example, mass movement hazards could be reduced by aligning water mains away from topographic low spots susceptible to gully formation and away from hillslopes that may be susceptible to creeping displacements that stress pipes and cause leaks. Pipeline specifications could also be changed to promote greater ductility, or resistance to failure, under hillslope displacement (Honegger et al., 2010; Han et al., 2012). In turn, the water resources infrastructure would benefit from fewer leaks and breaks and higher levels of reliability.

The decadal development of the urban surface is a critical control on the occurrence of WRIFs. While other have stud- ies described mega-gullies that develop over years (Archibold et al., 2003; Makanzu Imwangana et al., 2014) or hours (Moeyersons et al., 2015), mega-gullies in our study site can develop over single-storm events due to WRIFs, and they pose significant "abrupt" hazards to the population. Any latency between urbanization and WRIFs is due to delay in the installation of water infrastructure, as settlement and road construction commonly precede installation of sub-surface water infrastructure by several years. The spatial location of the WRIFs is governed by the temporal sequence of urbanization and land cover transformation that occurs over decades (Biggs et al., 2010). In Tijuana, mega-gullies occurred on unpaved roads in relatively recently urbanized areas $(<20$ years as urban) in the poor periphery, where the water distribution network was buried $\sim 0.5-1 \mathrm{~m}$ below the surface and easily undermined by rainfall-runoff erosion of the unpaved road. Satellite observations suggest roads have remained unpaved for decades following urbanization in Tijuana (Biggs et al., 2010), with consequent chronic exposure of the community to WRIFs. Roads are gradually paved over several decades, starting with the main transit corridors and followed by smaller roads in residential neighborhoods. As the network is paved, the water distribution network is more protected from road destruction during storm events. We thus anticipate that the occurrence of mega-gullies due to WRIFs will become less common with build-out and road paving but could remain a chronic problem in marginalized neighborhoods on the urban periphery, where socioeconomic status is low (Biggs et al., 2014). The landslide, by contrast, occurred in an area that had been urbanized for longer ( $\sim 40$ years); this kind of hazard could occur in older and wealthier neighborhoods on steep slopes if the water supply network develops leaks (Oliva-González et al., 2014). While other factors such as overloading by heavy construction and water towers may contribute to landslides in some urban contexts, the buildings in our study were single-story single-family residential units with minimal foundations and likely small impact on landslide risk (Demoulin and Hans-Balder, 2022). Rather, overloading by soil moisture from WRIFs was likely the trigger of the landslide in Tijuana.

\subsection{Implications for hazard mitigation in other urban contexts}

This study represents one of the first instances where abrupt mega-gully formation by water infrastructure failure has been documented in an urban environment. Such WRIF mega-gullies may be under-reported due to their occurrence in the poor urban periphery, and more research is needed to support sustainable, safe, and equitable urban environments for poor communities. Landslides and mega-gullies like those observed in Tijuana have been reported across cities not only in middle- and low-income countries where unregulated settlement occurs on steep hillslopes (e.g., landslides in Anderson et al., 2014) but also in developed countries. For 
example, in the city of San Diego, California (USA), soil erosion caused by a storm on 5 January 2016 undermined a $9.1 \mathrm{~m}$ long section of a sewer system, causing failure and prompting a spill of more than $30000 \mathrm{~m}^{3}$ of untreated sewage that severely eroded the riverbank and negatively impacted downstream ecosystems (Garrick, 2020). Nevertheless, what is clear is that even though the sample size of events reported in this analysis is small, the severity of the hazards involving WRIFs is high. Housing, transportation, and utilities that serve hundreds of people living in the watershed are impacted by WRIFs in Tijuana, and such conditions are likely to occur throughout the poor urban periphery, contributing to the vulnerability of marginalized populations to environmental hazards. WRIF-based mass movements have also contributed a significant amount of sediment to the total watershed load, which have negatively impacted habitat and aquatic ecosystems and further increased downstream infrastructure maintenance costs (Brand et al., 2020). Acknowledging the challenges of monitoring, as addressed here, what becomes clear is a need for more widespread monitoring of landslides and mega-gullies and documentation regarding the role of WRIFs. It is possible that a substantial fraction of the most hazardous mass movement events in cities are linked to WRIFs and that significant hazard reduction can be realized by addressing WRIFs.

\section{Conclusions}

Erosional features within a small $\left(11.6 \mathrm{~km}^{2}\right)$ watershed on the urban periphery of Tijuana, Mexico, were monitored to document the frequency and dimension of mega-gullies and landslides, including the volumes of sediment generated. Structure-from-motion (SfM) photogrammetric techniques helped to rapidly and safely assess the volume and shape of mega-gullies and landslides. Using imagery collected by either unmanned aerial systems (UASs) or a camera on a handheld pole, SfM techniques registered digital surface models (DSMs) with $\sim 3 \mathrm{~cm}$ horizontal RMSE and $\sim 5 \mathrm{~cm}$ vertical RMSE, which is in line with the needs for sediment budget applications. The methods presented here have the potential to be applied to other rapidly urbanizing watersheds throughout the world.

Over a 5-year period with 14 storm events, two megagullies and one landslide were observed during non-extreme rainfall events corresponding to a 1-2-year return period. The landslide damaged more than 20 homes and put roughly 100 people at risk, also affecting public transportation and the quality of life permanently. SfM analysis shows the landslide mobilized more sediment $(31900 \pm 280 \mathrm{mt})$ than all of the rainfall-based processes combined over the timescale of the rainfall event. The two mega-gullies interrupted water supplies for a month and disrupted public transportation and life quality for roughly 6 months. The SfM analysis showed the largest mega-gully generated $4340 t$ of sedi- ment, which is approximately 80 times the area-normalized annual erosion rate for rainfall gullies $\left(\mathrm{tha}^{-1}\right)$. While the link between rainfall and erosion hazards is well known, observations and interviews with residents indicated that all three events were associated with a water resources infrastructure failure (WRIF). Mega-gullies occurred after a break in a water supply pipe, which unleashed a highly erosive, high-velocity water jet onto an erodible hillslope, destroying an unpaved road and interrupting the water supply for weeks. Moreover, pipe breaks occurred after rainfall and runoff formed a small gully that undermined shallow structural support for the water supply pipe. Hence, we conjecture that the observed WRIF-based landslide formed according to the following two-step process:

1. A water main leak saturated the hillslope creating the preconditions for a landslide.

2. Rainfall triggered the landslide.

We also conjecture that the WRIF-based mega-gully formed according to the following two-step process:

1. A water supply pipe breaks after a rainfall-generated gully network undermines the pipe.

2. A mega-gully is formed from the water released from the broken water supply line.

The limited data suggest that WRIF-based erosion events occur with an annual frequency of $40 \%-60 \%$, which is far higher than typical design standards for stormwater infrastructure (5\%-10\% annual exceedance probability). Modeling shows that WRIFs contribute, on average, $5 \%$ of the total annual sediment generation at the watershed scale and up to $58 \%$ on a storm-event basis. Additional research is needed to improve estimates of the spatial and temporal frequency of erosional features caused by WRIFs and to understand the significance of WRIF hazards at other spatial and temporal scales and in other geographic contexts. Furthermore, the hazards posed by WRIFs within development on steep terrain call for greater attention to infrastructure design and maintenance. While the sample size of this study is small, the results suggest that poorly maintained water distribution networks on the marginalized urban periphery can be the single most important process generating earth surface hazards, and this finding calls for further investigation into the prevalence of these mechanisms elsewhere. These results also point to opportunities for hazard reduction within urban peripheries through the improved planning, design, and maintenance of water distribution infrastructure.

Code and data availability. Field collection and the SfMprocessed DSMs are not publicly available because the authors are conducing further analyses. However, the entire dataset used and/or analyzed in this research is available from the corresponding author upon a reasonable request. 
Author contributions. NGE undertook data acquisition, processing, and interpretation of the data and prepared the manuscript with contributions from all co-authors. BFS, TWB, MWB, and AGG designed the research and co-authored the manuscript. EL and YY coauthored the manuscript and assisted with manuscript preparation, and $\mathrm{RB}$ provided valuable guidance on the soil erosion modeling. AHC coordinated and supervised the landslide survey and contributed to the final revision of the manuscript.

Competing interests. The contact author has declared that neither they nor their co-authors have any competing interests.

Disclaimer. The statements, findings, conclusions, and recommendations are those of the author(s) and do not necessarily reflect the views of NOAA or USEPA.

Publisher's note: Copernicus Publications remains neutral with regard to jurisdictional claims in published maps and institutional affiliations.

Acknowledgements. Special thanks to Thomas Kretzschmar, Kristine Taniguchi-Quan, and Belinda Sandoval, whose support on field collection and data analysis is gratefully acknowledged. We thank Sergio Arregui, Luis Gradilla, Clemente Gallardo, and Octavio Meillon from CICESE for their support during the landslide UAS survey. We thank Tijuana Metropolitan Planning Institute (IMPLAN) for data sharing. Thanks also to residents of the Los Laureles Canyon, who provided valuable help for data collection.

Financial support. This research has been supported by the National Oceanic and Atmospheric Administration Ecological Effects of Sea Level Rise Program (award NA16NOS4780206) and the US Environmental Protection Agency (EPA) (Interagency Agreement ID no. DW-12-92390601-0) in collaboration with the US Department of Agriculture (USDA, Agreement 58-6408-4-015), San Diego State University (USA), and the Centro de Investigación Científica y de Educación Superior de Ensenada (CICESE, México).

Review statement. This paper was edited by David J. Peres and reviewed by two anonymous referees.

\section{References}

Adediji, A., Jeje, L. K., and Ibitoye, M. O.: Urban development and informal drainage patterns: Gully dynamics in Southwestern Nigeria, Appl. Geogr., 40, 90-102, https://doi.org/10.1016/j.apgeog.2013.01.012, 2013.

Alfonso-Torreño, A., Gómez-Gutiérrez, A., Schnabel, S., LavadoContador, J. F., de San jose-Blasco, J. J., and SánchezFernandez, M.: sUAS, SfM-MVS photogrammetry and a topographic algorithm method to quantify the volume of sediments retained in check-dams, Sci. Total Environ., 678, 369-382, https://doi.org/10.1016/j.scitotenv.2019.04.332, 2019.

Anderson, M. G., Holcombe, E., Holm-Nielsen, N., and Della Monica, R.: What Are the Emerging Challenges for Community-Based Landslide Risk Reduction in Developing Countries?, Nat. Hazards Rev., 15, 128-139, https://doi.org/10.1061/(ASCE)NH.1527-6996.0000125, 2014.

Archibold, O. W., Levesque, L. M. J., de Boer, D. H., Aitken, A. E., and Delanoy, L.: Gully retreat in a semi-urban catchment in Saskatoon, Saskatchewan, Appl. Geogr., 23, 261-279, https://doi.org/10.1016/j.apgeog.2003.08.005, 2003.

Bianchini, S., Raspini, F., Ciampalini, A., Lagomarsino, D., Bianchi, M., Bellotti, F., and Casagli, N.: Mapping landslide phenomena in landlocked developing countries by means of satellite remote sensing data: the case of Dilijan (Armenia) area, Geomatics, Nat. Hazards Risk, 8, 225-241, https://doi.org/10.1080/19475705.2016.1189459, 2017.

Biggs, T. W., Atkinson, E., Powell, R., and Ojeda-Revah, L.: Land cover following rapid urbanization on the USMexico border: Implications for conceptual models of urban watershed processes, Landsc. Urban Plan., 96, 78-87, https://doi.org/10.1016/j.landurbplan.2010.02.005, 2010.

Biggs, T. W., Anderson, W. G., and Pombo, O. A.: Concrete and Poverty, Vegetation and Wealth? A Counterexample from Remote Sensing of Socioeconomic Indicators on the U.S.-Mexico Border, The Professional Geographer, 1-14, https://doi.org/10.1080/00330124.2014.905161, 2014.

Biggs, T. W., Taniguchi, K. T., Gudino-Elizondo, N., Langendoen, E. J., Yuan, Y., Bingner, R. L., and Liden, D.: Runo? and Sediment Yield on the US-Mexico Border, Los Laureles Canyon,Report EPA/600/R-18/365, US Environmental Protection Agency, Washington, DC, USA, https://cfpub.epa.gov/si/ si_public_record_report.cfm?dirEntryId=343214\&Lab=NERL (last access: 3 October 2020), 2017.

Bingner, R. L., Theurer, F. D., Yuan, Y., and Taguas, E.: AnnAGNPS Technical Processes, US Department of Agriculture (USDA) - Agricultural Research Service (ARS), Washington, DC, https://www.wcc.nrcs.usda.gov/ftpref/wntsc/H\&H/AGNPS/ downloads/AnnAGNPS_Technical_Documentation.pdf (last access: 5 July 2020), 2015.

Borelli, S., Conigliaro, M., Quaglia, S., and Salbitano, F.: Urban and Peri-urban agroforestry as multifunctional land use. Agroforestry: Anecdotal to Modern Science, Springer Nature, Singapore, 705-725, https://doi.org/10.1007/978-981-10-7650-3_28, 2018.

Brand, M. W., Gudiño-Elizondo, N., Allaire, M., Wright, S., Matson, W., Saksa, P., and Sanders, B. F.: Stochastic Hydro-Financial Watershed Modeling for Environmental Impact Bonds, Water Resour. Res., 56, e2020WR027328, https://doi.org/10.1029/2020WR027328, 2020. 
Calvello, M., Papa, M. N., and Pratschke, J.: Landslide risk perception: a case study in Southern Italy, Landslides, 13, 349-360, https://doi.org/10.1007/s10346-015-0572-7, 2016.

Carrera-Hernández, J. J., Levresse, G., and Lacan, P.: Is UAV-SfM Surveying Ready to Replace Traditional Surveying Techniques?, Int. J. Remote Sens., 41, 4818-4835, https://doi.org/10.1080/01431161.2020.1727049, 2020.

Castillo, C. and Gómez, A.: A century of gully erosion research: Urgency, complexity and study approaches, Earth-Sci. Rev., 160, 300-319, https://doi.org/10.1016/j.earscirev.2016.07.009, 2016.

Castillo, C., James, M. R., Redel-Macías, M. D., Pérez, R., and Gómez, J. A.: SF3M software: 3-D photo-reconstruction for nonexpert users and its application to a gully network, Soil, 1, 583594, https://doi.org/10.5194/soil-1-583-2015, 2015.

Cook, P.: Infrastructure, rural electrification and development, Energy Sustain. Dev., 15, 304-313, https://doi.org/10.1016/j.esd.2011.07.008, 2011.

Costa, C. W., Lorandi, R., de Lollo, J. A., Imani, M., and Dupas, F. A.: Surface runof and accelerated erosion in a peri-urban wellhead area in southeastern Brazil, Environ. Earth Sci., 77, 160, https://doi.org/10.1007/s12665-018-7366-x, 2018.

Criqui, L.: Infrastructure Urbanism: Roadmaps for Servicing Unplanned Urbanisation in Emerging Cities, Habitat Int., 47, 93102, https://doi.org/10.1016/j.habitatint.2015.01.015, 2015.

de Albuquerque, A. O., de Carvalho Júnior, O. A., Guimaraes, R. F., Gomes, R. A. T., and Hermuche, P. M.: Assessment of gully development using geomorphic change detection between preand post-urbanization scenarios. Environ. Earth Sci., 79, 232, https://doi.org/10.1007/s12665-020-08958-9, 2020.

Demoulin, A. and Hans-Balder, H.: Causes and Triggers of MassMovements: Overloading, Treat. Geomorphol., in press, 2022.

Dietrich, J. T.: Riverscape mapping with helicopter-based Structure from-Motion photogrammetry, Geomorphology, 252, 144-157, https://doi.org/10.1016/j.geomorph.2015.05.008, 2016.

Eltner, A., Kaiser, A., Castillo, C., Rock, G., Neugirg, F., and Abellán, A.: Image-based surface reconstruction in geomorphometry - merits, limits and developments, Earth Surf. Dynam., 4, 359389, https://doi.org/10.5194/esurf-4-359-2016, 2016.

Ercoli, R. F., Matias, V. R. S., and Zago, V. C. P.: Urban Expansion and Erosion Processes in an Area of Environmental Protection in Nova Lima, Minas Gerais State, Brazil. Front. Environ. Sci., 8, 52, https://doi.org/10.3389/fenvs.2020.00052, 2020.

Fu, S., Chen, L., Woldai, T., Yin, K., Gui, L., Li, D., Du, J., Zhou, C., Xu, Y., and Lian, Z.: Landslide hazard probability and risk assessment at the community level: A case of western Hubei, China, Nat. Hazards Earth Syst. Sci., 20, 581-601, https://doi.org/10.5194/nhess-20-581-2020, 2020.

Fugazza, D., Scaioni, M., Corti, M., D’Agata, C., Azzoni, R. S., Cernuschi, M., Smiraglia, C., and Diolaiuti, G. A.: Combination of UAV and terrestrial photogrammetry to assess rapid glacier evolution and map glacier hazards, Nat. Hazards Earth Syst. Sci., 18, 1055-1071, https://doi.org/10.5194/nhess18-1055-2018, 2018.

Garrick, D.: San Diego paying \$2.5M fine for 2016 sewage spill in Tecolote Canyon, Mission Bay, The San Diego Union-Tribune, https://www.sandiegouniontribune.com/, last access: 16 October 2020 .
Gastil, R. G., Phillips, R., and Allison, E.: Reconnaissance geology of the State of Baja California, Geol. Soc. Am. Memoir, 140, 170, https://doi.org/10.1130/MEM140-p1, 1975.

Gilbert, G. K.: Hydraulic-mining debris in the Sierra Nevada, US Geol. Surv. Prof Pap. 105, 154 pp., https://play.google.com/ books/reader?id=D3TnAAAAMAAJ\&pg=GBS.PA10\&hl=es (last access: 6 February 2022), 1917.

Goodrich, K. A., Basolo, V., Feldman, D. L., Matthew, R. A., Schubert, J. E., Luke, A., Eguiarte, A., Boudreau, D., Serrano, K., Reyes, A. S. Contreras, S., Houston, D., Cheung, W., AghaKouchak A., and Sanders, B. F.: Addressing Pluvial Flash Flooding through Community-Based Collaborative Research in Tijuana, Mexico, Water, 12, 1257, https://doi.org/10.3390/w12051257, 2020.

Griffin, E. and Ford, L.: A model of Latin American city structure, Geogr. Rev., 70, 397-422, 1980.

Gudino-Elizondo, N., Biggs, T. W., Castillo, C., Bingner, R., Langendoen, E., Taniguchi, K., Kretzschmar, T., Yuan, Y., and Liden, D.: Measuring ephemeral gully erosion rates and topographical thresholds in an urban watershed using Unmanned Aerial Systems and structure from motion photogrammetric techniques, Land Degrad. Dev., 29, 1896-1905, https://doi.org/10.1002/ldr.2976, 2018a.

Gudino-Elizondo, N., Biggs, T. W., Bingner, R. L., Yuan, Y., Langendoen, E. J., Taniguchi, K. T., Kretzschmar, T., Taguas, E. V., and Liden, D.: Modelling Ephemeral Gully Erosion from Unpaved Urban Roads: Equifinality and Implications for Scenario Analysis, Geosciences, 8, 137, https://doi.org/10.3390/geosciences8040137, 2018b.

Gudino-Elizondo, N., Biggs, T. W., Bingner, R. L., Yuan, Y., Langendoen, E. J., Kretzschmar, T., Taguas, E. V., Taniguchi, K. T., and Liden, D.: Modelling Runo? and Sediment Loads in a Developing Coastal Watershed of the US-Mexico Border, Water, 11, 1024, https://doi.org/10.3390/w11051024, 2019.

Guo, S., Shao, Y., Zhang, T. Q., Zhu, D. Z., and Zhang, Y. P.: Physical modeling on sand erosion around defective sewer pipes under the influence of groundwater, J. Hydraul. Eng., 139, 1247-57, https://doi.org/10.1061/(ASCE)Hy.1943-7900.0000785, 2013.

Han, B., Wang, Z., Zhao, H., Jing, H., and Wu, Z.: Strain-Based Design for Buried Pipelines Subjected to Landslides, Pet. Sci., 9, 236-241, https://doi.org/10.1007/s12182-012-0204-y, 2012.

Hardoy, J. E., Mitlin, D., and Sattterwaite, D.: Environmental Problems in an Urbanizing World, 2nd Edn., Routledge, London, https://doi.org/10.4324/9781315071732, 2013.

Honegger, D. G., Hart, J. D., Phillips, R., Popelar, C., and Gailing, R. W.: Recent PRCI Guidelines for Pipelines Exposed to Landslide and Ground Subsidence Hazards, in: Proceedings of the 8th International Pipeline Conference, Calgary, AB, IPC201031311, 1-10, 2010.

Highland, L. and Bobrowsky, P. T.: The landslide handbook: a guide to understanding landslides, Circular 1325, US Geological Survey, p. 129, https://pubs.usgs.gov/circ/1325/ (last access: 6 February 2022), 2008.

Izumida, A., Uchiyama, S., and Sugai, T.: Application of UAV-SfM photogrammetry and aerial lidar to a disastrous flood: repeated topographic measurement of a newly formed crevasse splay of the Kinu River, central Japan, Nat. Hazards Earth Syst. Sci., 17, 1505-1519, https://doi.org/10.5194/nhess-17-1505-2017, 2017. 
James, L. A., Hodgson, M. E., Ghoshal, S., and Latiolais, M. M.: Geomorphic change detection using historic maps and DEM differencing: the temporal dimension of geospatial analysis, Geomorphology, 137, 181-198, https://doi.org/10.1016/j.geomorph.2010.10.039, 2012.

James, M. R. and Robson, S.: Straightforward reconstruction of $3 \mathrm{D}$ surfaces and topography with a camera: Accuracy and geosciences applications, J. Geophys. Res., 117, 1-17, https://doi.org/10.1029/2011JF002289, 2012.

James, M. R. and Robson, S.: Mitigating systematic error in topographic models derived from UAV and ground-based image networks, Earth Surf. Proc. Land., 39, 1413-1420, https://doi.org/10.1002/esp.3609, 2014.

James, M. R., Robson, S., d'Oleire-Oltmanns, S., and Niethammer, U.: Optimising UAV topographic surveys processed with structure-from-motion: Ground control quality, quantity and bundle adjustment, Geomorphology, 280, 51-66, https://doi.org/10.1016/j.geomorph.2016.11.021, 2017.

James, M. R., Chandler, J. H., Eltner, A., Fraser, C., Miller, P. E., Mills, J. P., Noble, T., Robson, S., and Lane, S. N.: Guidelines on the use of structure-from-motion photogrammetry in geomorphic research, Earth Surf. Proc. Land., 44, 2081-2084, https://doi.org/10.1002/esp.4637, 2019.

Kaiser, A., Erhardt, A., and Eltner, A.: Addressing uncertainties in interpreting soil surface changes by multitemporal highresolution topography data across scales, Land Degrad. Dev., 29, 2264-2277, https://doi.org/10.1002/ldr.2967, 2018.

Kim, K., Kim, J., Kwak, T. Y., and Chung, C. K.: Logistic regression model for sinkhole susceptibility due to damaged sewer pipes, Nat. Hazards, 93, 765-785, https://doi.org/10.1007/s11069-0183323-y, 2018.

Kjekstad, O., and Highland, L.: Economic and social impacts of landslides, in: Landslides - disaster risk reduction, edited by: Zhou, L., Ooi, B. C., and Meng, X., Springer, Berlin, Heidelberg, 573-587, https://doi.org/10.1007/978-3-540-69970-5_30, 2009.

Kuo, H. L., Lin, G. W., Chen, C. W., Saito, H., Lin, C. W., Chen, H., and Chao, W. A.: Evaluating critical rainfall conditions for large-scale landslides by detecting event times from seismic records, Nat. Hazards Earth Syst. Sci., 18, 2877-2891, https://doi.org/10.5194/nhess-18-2877-2018, 2018.

Lacroix, P., Dehecq, A., and Taipe, E.: Irrigation-triggered landslides in a Peruvian desert caused by modern intensive farming, Nat. Geosci., 13, 56-60, https://doi.org/10.1038/s41561019-0500-x, 2020.

Luke, A., Sanders, B. F., Goodrich, K. A., Feldman, D. L., Boudreau, D., Eguiarte, A., Serrano, K., Reyes, A., Schubert, J. E., AghaKouchak, A., Basolo, V., and Matthew, R. A.: Going beyond the flood insurance rate map: insights from flood hazard map co-production, Nat. Hazards Earth Syst. Sci., 18, 10971120, https://doi.org/10.5194/nhess-18-1097-2018, 2018.

Ma, S., Wei, J., Xu, C., Shao, X., Xu, S., Chai, S., and Cui, Y.: UAV survey and numerical modeling of loess landslides: an example from Zaoling, southern Shanxi Province, China, Nat. Hazards, 104, 1125-1140, https://doi.org/10.1007/s11069-02004207-1, 2020.

Makanzu Imwangana, F., Dewitte, O., Ntombi, M., and Moeyersons, J.: Topographic and road control of mega-gullies in Kinshasa (DR Congo), Geomorphology, 217, 131-139, https://doi.org/10.1016/j.geomorph.2014.04.021, 2014.
Makanzu Imwangana, F., Vandecasteele, I., Trefois, P., Ozer, P., and Moeyersons, J.: The origin and control of megagullies in Kinshasa (D. R. Congo), Catena, 125, 38-49, https://doi.org/10.1016/j.catena.2014.09.019, 2015.

Marino, P., Peres, D. J., Cancelliere, A., Greco, R., and Bogaard, T. A.: Soil moisture information can improve shallow landslide forecasting using the hydrometeorological threshold approach, Landslides, 17, 2041-2054, https://doi.org/10.1007/s10346-02001420-8, 2020.

Mazzoleni, M., Paron, P., Reali, A., Juizo, D., Manane, J., and Brandimarte, L.: Testing UAV-derived topography for hydraulic modelling in a tropical environment, Nat. Hazards, 103, 139163, https://doi.org/10.1007/s11069-020-03963-4, 2020.

McAdoo, B. G., Quak, M., Gnyawali, K. R., Adhikari, B. R., Devkota, S., Rajbhandari, P. L., and Sudmeier-Rieux, K.: Roads and landslides in Nepal: how development affects environmental risk, Nat. Hazards Earth Syst. Sci., 18, 3203-3210, https://doi.org/10.5194/nhess-18-3203-2018, 2018.

Miller, J. R., Ferri, K., Grow, D., and Villarroel, L.: Hydrologic, geomorphic, and stratigraphic controls on suspended sediment transport dynamics, Big Harris Creek restoration site, North Carolina, USA, Anthropocene, 25, 100188, https://doi.org/10.1016/j.ancene.2018.12.002, 2019.

Minch, A. J., Ashby, J., Deméré, T., and Kuper, T.: Correlation and depositional environments of the Middle Miocene Rosarito Beach Formation of northwestern Baja California, Mexico, in: Miocene and Cretaceous depositional environments, northwestern Baja California, Mexico: Pacific Section, edited by: Minch, J. A. and Ashby, J. R., American Association of Petroleum Geologists, 33-46, 1984.

Moeyersons, J., Makanzu Imwangana, F., and Dewitte, O.: Siteand rainfall-specific runoff coefficients and mega-gully development in Kinshasa (DR Congo), Nat. Hazards, 79, 203-233, https://doi.org/10.1007/s11069-015-1870-z, 2015.

Monsieurs, E., Dewitte, O., and Demoulin, A.: A susceptibilitybased rainfall threshold approach for landslide occurrence, Nat. Hazards Earth Syst. Sci., 19, 775-789, https://doi.org/10.5194/nhess-19-775-2019, 2019.

Nadal-Romero, E., Revuelto, J., Errea, P., and López-Moreno, J. I.: The application of terrestrial laser scanner and SfM photogrammetry in measuring erosion and deposition processes in two opposite slopes in a humid badlands area (central Spanish Pyrenees), Soil, 1, 561-573, https://doi.org/10.5194/soil-1-561-2015, 2015.

NOAA - National Oceanic and Atmospheric Administration: Precipitation Frequency Data Server, https://hdsc.nws.noaa.gov/ hdsc/pfds/pfds_map_cont.html, last access: 24 December 2021.

Oliva-González, A. O., Jiménez, D. M., Alvarez-Garcia, I. N., Nicieza, C. G., and Álvarez-Vigil, A. E.: Hillside instability in the Tijuana metropolitan area. Analysis of landslideprovoked building collapse, Eng. Fail. Anal., 46, 166-178, https://doi.org/10.1016/j.engfailanal.2014.08.004, 2014.

Peng, L., Lin, L., Liu, S. Q., and Xu, D.: Interaction between risk perception and sense of place in disaster-prone mountain areas: A case study in China's Three Gorges Reservoir Area, Nat. Hazards, 85, 777-792, https://doi.org/10.1007/s11069-016-2604-6, 2017. 
Poesen, J.: Soil erosion in the Anthropocene: Research needs, Earth Surf. Proc. Land., 43, 64-84, https://doi.org/10.1002/esp.4250, 2018.

Retief, F., Bond, A., Pope, J., Morrison-Saunders, A., and King, N.: Global megatrends and their implications for environmental assessment practice, Environ. Impact Assess. Rev., 61, 52-60, https://doi.org/10.1016/j.eiar.2016.07.002, 2016.

Sepúlveda, S. A. and Petley, D. N.: Regional trends and controlling factors of fatal landslides in Latin America and the Caribbean, Nat. Hazards Earth Syst. Sci., 15, 1821-1833, https://doi.org/10.5194/nhess-15-1821-2015, 2015.

Sidle, R., Furuichi, T., and Kono, Y.: Unprecedented rates of landslide and surface erosion along a newly constructed road in Yunnan, China, Nat. Hazards, 57, 313-326, https://doi.org/10.1007/s11069-010-9614-6, 2011.

Taniguchi, K. T., Biggs, T. W., Langendoen, E. J., Castillo, C., Gudino-Elizondo, N., Yuan, Y., and Liden, D.: Stream channel erosion in a rapidly urbanizing region of the US-Mexico border: Documenting the importance of channel hardpoints with Structure from-Motion photogrammetry, Earth Surf. Proc. Land., 43, 1465-1477, https://doi.org/10.1002/esp.4331, 2018.

USDA: Estimating Moist Bulk Density by Texture, https://www.nrcs.usda.gov/wps/portal/nrcs/detail/soils/survey/ office/ssr10/tr/?cid=nrcs144p2_074844 (last access: 3 September 2019), 2018.

Valentin, C., Poesen, J., and Li, Y.: Gully erosion: Impacts, factors and control, Catena, 63, 132-153, https://doi.org/10.1016/j.catena.2005.06.001, 2005.

Valenzuela, P., Domínguez-Cuesta, M. J., García, M. A. M., and Jiménez-Sánchez, M.: Rainfall thresholds for the triggering of landslides considering previous soil moisture conditions (Asturias, NW Spain), Landslides, 15, 273-282, https://doi.org/10.1007/s10346-017-0878-8, 2018.

Vanmaercke, M., Poesen, J., Van Mele, B., Demuzere, M., Bruynseels, A., Golosov, V., Rodrigues Bezerra, J., Bolysov, S., Dvinskih, A., Frankl, A., Fuseina, Y., Guerra, A., Haregeweyn, N., Ionita, I., Makanzu Imwangana, F., Moeyersons, J., Moshe, I., Nazari Samani, A., Niacsui, L., Nyssen, J., Otsuki, Y., Radoane, M., Rysin, I., Ryzhov, Y., and Yermolaev, O.: How fast do gully headcuts retreat?, Earth-Sci. Rev., 154, 336-355, https://doi.org/10.1016/j.earscirev.2016.01.009, 2016.

Vanmaercke, M., Panagos, P., Vanwalleghem, T., Hayas, A., Foersterf, S., Borrelli, P., Rossi, M., Torri, D., Casali, J., Borselli, L., Vigiak, O., Maerkerl, M., Haregeweyn, N., De Geeter, S., Zgłobicki, W., Bielders, C., Cerdà, A., Conoscenti, C., de Figueiredo, T., Evans, B., Golosov, V., Ionita, I., Karydas, C., Kertész, A., Krasa, J., Le Bouteiller, C., Radoane, M., Ristić, R., Rousseva, S., Stankoviansky, M., Stolte, J., Stolz, C., Bartley, R., Wilkinson, S., Jarihani, B., and Poesen, J.: Measuring, modelling and managing gully erosion at large scales: a state of the art, Earth Sci. Rev., 218, 103637, https://doi.org/10.1016/j.earscirev.2021.103637, 2021.
Van Zyl, J. E., Alsaydalani, M. O., Clayton, C. R., Bird, T., and Dennis, A.: Soil fluidisation outside leaks in water distribution pipes - Preliminary observations, J. Water Manage., 166, 546555, https://doi.org/10.1680/wama.11.00119, 2013.

Vigiak, O., Borselli, L., Newham, L. T. H., McInnes, J., and Roberts, A. M.: Comparison of conceptual landscape metrics to define hillslope-scale sediment delivery ratio, Geomorphology, 138, 74-88, https://doi.org/10.1016/j.geomorph.2011.08.026, 2012.

Weis, D. A., Callaway, J. C., and Gersberg, R. M.: Vertical accretion rates and heavy metal chronologies in wetland sediments of the Tijuana Estuary, Estuaries, 24, 840-850, https://doi.org/10.2307/1353175, 2001.

Wheaton, J. M., Brasington, J., Darby, S. E., and Sear, D. A.: Accounting for uncertainty in DEMs from repeat topographic surveys: improved sediment budgets, Earth Surf. Proc. Land., 35, 136-156, https://doi.org/10.1002/esp.1886, 2010.

Whittington, D., Davis, J., Prokopy, L., Komives, K., Thorsten, R., Lukacs, H., Bakalian, A., and Wakeman, W.: How well is the demand-driven, community management model for rural water supply systems doing? Evidence from Bolivia, Peru and Ghana, Water Policy, 11, 696-718, https://doi.org/10.2166/wp.2009.310, 2009.

Zhang, H., Aldana-Jague, E., Clapuyt, F., Wilken, F., Vanacker, V., and Van Oost, K.: Evaluating the potential of post-processing kinematic (PPK) georeferencing for UAV-based structure-frommotion (SfM) photogrammetry and surface change detection, Earth Surf. Dynam., 7, 807-827, https://doi.org/10.5194/esurf7-807-2019, 2019.

Zhuo, L., Dai, Q., Han, D., Chen, N., Zhao, B., and Berti, M.: Evaluation of remotely sensed soil moisture for landslide hazard assessment, IEEE J. Select. Top. Appl. Earth Obs. Remote Sens., 29, 849-859, https://doi.org/10.1109/JSTARS.2018.2883361, 2019.

Zolezzi, G., Bezzi, M., Spada, D., and Bozzarelli, E.: Urban gully erosion in sub-Saharan Africa: a case study from Uganda, Land. Degrad. Dev., 29, 849-859, https://doi.org/10.1002/ldr.2865, 2018. 